\title{
Surveilans Epidemiologi Kasus Terkonfirmasi COVID-19 pada Pasien Rawat Inap di Rumah Sakit Pusat Infeksi Prof. Dr. Sulianti Saroso Tahun 2020
}

\author{
Epidemiological surveillance of COVID-19 Confirmed Case Inpatient Care in National \\ Infection Centre Prof Dr Sulianti Saroso in 2020
}

\author{
Herlina*, Anita PD Nugroho, Siti Maemun, Intan Pertiwi, Farida Murtiani, A. Dala Intan SN \\ Rumah Sakit Penyakit Infeksi Prof. Dr. Sulianti Saroso ${ }^{1}$
}

*Korespondensi Penulis:

Herlina

Email: herlinadwinantomashud@gmail.com

\begin{abstract}
Abstrak
Latar Belakang: Surveilans epidemiologi adalah pengamatan terus menerus terhadap perkembangan kasus dan kematian melalui analisis dan intervensi epidemiologi yang terstandar dengan tujuan untuk membatasi penyebaran penyakit, sebagai bahan bagi pemerintah daerah, otoritas Kesehatan masyarakat dan rumah sakit untuk mengelola kasus penyakit (dalam hal ini COVID-19), surveilans juga dibutuhkan untuk memantau tren jangka panjang penularan COVID-19 dan perubahan virus. Metode: surveilans pasif dan aktif Surveilans pasif adalah surveilans dengan cara mengambil data dari sumber status pasien (rekam medik) dan laporan dari ruang perawatan, sementara surveilans aktif adalah mencari data langsung ke pasien (menanyakan langsung kepada pasien dengan cara menelpon ataupun melalui whatsapp ). Hasil: Jumlah pasien rawat inap COVID-19 tahun 2021 sebanyak 1065 pasien, sebagian besar kasus antara lain laki-laki (573 pasien), kelompok umur $>18$ tahun (1028 pasien), domisili Jakarta Utara (288 pasien), datang sendiri (35\%)., sebagian besar pasien keluar hidup (911 pasien) dan hasil PCR terkonfirmasi (880 pasien). Kesimpulan: Pelaksanaan surveilans epidemiologi kasus COVID-19 di RSPI Sulianti Saroso berdasarkan orang, tempat dan waktu ( variable jumlah kasus, umur, jenis kelamin, asal domisili, pemeriksaan, luaran pasien dan asal rujukan). Surveilans sangat dibutuhkan untuk evaluasi pelayanan dan program penanggulangan penyakit, oleh karena itu dibutuhkan dukungan kelengkapan data dan ketepatan waktu pelaporan untuk mendapatkan data yang valid.
\end{abstract}

Kata Kunci: COVID-19, Surveilans

\begin{abstract}
Background: Epidemiological surveillance is continuous observation of the development of cases and deaths through standardized analysis and epidemiology with the aim of limiting the spread of disease, as a material for local governments, public health authorities and hospitals to manage cases (in this case COVID-19), surveillance also needed to unify the long-term trends of COVID-19 transmission and changes in the virus. Methods: passive and active surveillance Passive surveillance is surveillance by taking data from sources of patient status (medical records) and reports from the treatment room, while active surveillance is looking for data directly to patients (asking directly to patients by calling or via whatsapp). Results: The number of inpatients for COVID-19 in 2021 was 1065 patients, most of the cases were male (573 patients), age group >18 years 1028 patients, domiciled in North Jakarta (288 patients), came alone (35\% ), most of the patients were discharged alive (911 patients) and the PCR results were confirmed (880 patients). Conclusions: Implementation of epidemiological surveillance of COVID-19 cases at RSPI Sulianti Saroso based on person, place and time (variables of number of cases, age, gender, origin of domicile, examination, patient outcomes and origin of referrals). Surveillance is very much needed for service evaluation and disease prevention, therefore data support and timely reporting are needed to obtain valid data.
\end{abstract}

Keywords: COVID-19, Surveilans 


\section{Pendahuluan}

Coronavirus disease 2019 (COVID19) termasuk dalam penyakit menular yang baru muncul (new emerging disease). World Health Organization (WHO) menyatakan bahwa penyebab penyakit ini merupakan corona virus jenis baru yang belum pernah diidentifikasi sebelumnya pada manusia yang kemudian disebut dengan Severe Acute Resporatory Syndrome Coronavirus 2 (SARS-CoV-2). Pada 31 Desember 2019, WHO mengkorfirmasi kasus pneumonia yang penyebabnya tidak diketahui di Kota Wuhan, China. Pada tanggal 11 Maret 2020 terjadi peningkatan yang cepat untuk kasus di luar China dan kemudian sampai per 17 Agustus 2020 terdapat 21.516.760 terkonfirmasi kasus COVID-19 dengan 766.663 kematian di seluruh dunia yang berdampak pada 176 negara. ${ }^{1}$

Kasus COVID-19 yang terus meningkat di banyak negara membuat Organisasi Kesehatan Dunia (World Health Organization) menyatakan bahwa COVID-19 merupakan pandemic. Salah satu negara yang juga berdampak COVID-19 yaitu Indonesia dimana kasus pertama dilaporkan pada tanggal 2 Maret 2020. Sampai saat ini jumlah kasus terus meningkat dan menyebar di seluruh provinsi di Indonesia. Per 17 Agustus 2020 tedapat 1.068. 945 kasus positif dengan 6.207 kasus meninggal dan 483 kabupaten/kota terdampak. ${ }^{2}$

Penanggulangan Pandemi COVID19 sampai saat ini masih berlangsung, sehingga diperlukan suatu tindakan penemuan kasus dan pencegahan kasus. Adapun kegiatan tersebut dikenal dengan nama surveilans. ${ }^{3}$ Tujuan untuk dilakukan surveilans yaitu dapat memantau tren penularan COVID-19, melakukan deteksi cepat pada wilayah tanpa transmisi virus dan monitoring kasus pada wilayah dengan transmisi virus termausk pada populasi rentan, memberikan informasi epidemiologi untuk melakukan penilaian risiko, memberikan informasi epidemiologi sebagai acuan kesiapsigaan dan respon penanggulangan serta memberikan evaluasi terhadap dampak pandemic pada sistem pelayanan kesehatan dan sosial. ${ }^{(2)}$ Peningkatan kasus COVID-19 masih terjad di Indonesia dan DKI Jakarta merupakan kasus terbanyak sampai saat ini maka diperlukan sosialisasi tentang surveilans untuk mengantipasi penambahan kasus yang lebih banyak lagi. ${ }^{4}$

Rumah Sakit Penyakit Infeksi Prof. Dr. Sulianti Saroso (RSPI-SS) merupakan salah satu rumah sakit rujukan nasional untuk kasus COVID19. RSPI-SS telah mulai menerima pasien terduga COVID-19 sejak bulan 
Januari 2020 kasus terkonfirmasi pertama di Indonesia, yaitu pada tanggal 3 Maret 2020 merupakan salah satu pasien yang di rawat di RSPI-SS, selanjutnya kasus terkonfirmasi positif terus meningkat. Surveilans epidemiologi merupakan salah satu unit fugsional di RSPI-SS yang saat ini berada di bawah Instalasi Data dan Informasi. Laporan ini merupakan laporan tahunan surveilans epidemiologi untuk kasus COVID-19 rawat inap tahun 2020.

\section{Metode}

Desain kajian ini deskriptif cross sectional, dengan data sekunder bersumber dari data ruang rawat inap dan data SIMRS dan merupakan hasil dari kegiatan surveilans. Sampel yang terkumpul sebnayak 1065 sampel dengan kriteria inklusi yaitu seluruh pasien rawat inap periode waktu tahun 2020. Kajian ini telah mendapat ethical clearance dari komite etik RSPI Prof Dr Sulianti Saroso dengan nomor izin etik 33/XXXVIII.10/X/2021.

\section{Hasil}

Gambaran Kasus COVID-19 pada Psien Rawat Inap Di RSPI Sulianti Saroso Tahun 2020

Jumlah kasus meningkat setiap bulannya, dan tertinggi pada bulan Desember yaitu 170 kasus. Peningkatan kasus bulan Desember di RSPI-SS sesuai dengan peningkatan kasus di DKI Jakarta dan sekitarnya. Pada bulan Januari dan Februari belum didapatkan pasien terkonfirmasi COVID-19. Hasil terkonfirmasi pertama kali dilaporkan pada pada tanggal 2 Maret 2020 yang berasal dari wilayah Depok Jawa Barat (Grafik 1).

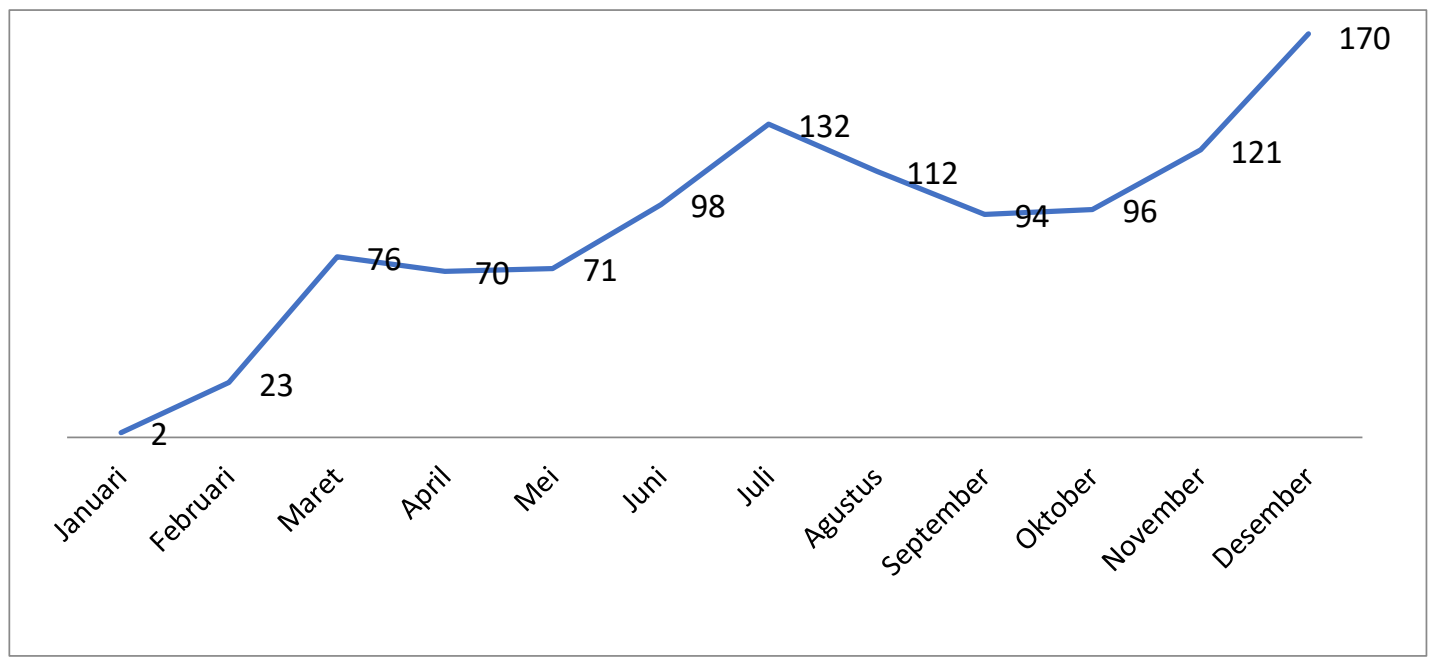

Grafik 1. Distribusi Pasien Rawat Inap COVID-19 di SPI-SS Berdasarkan Jumlah Kasus Per Bulan Tahun 2020 
Distribusi Pasien Rawat Inap

Berdasarkan Umur dan Jenis

Kelamin di RSPI Sulianti Saroso

Tahun 2020

Dari 1065 pasien COVID-19 enunjukkan sebagian besar kasus rawat inap adalah laki-laki (573 pasien) dan pada kelompok umur $>18$ tahun (548 pasien) maupun pada kelompok umur $\leq 18$ tahun (25 pasien) (Gambar 2).
Distribusi Pasien Rawat Inap COVID19 Berdasarkan Domisili di RSPI Sulianti Saroso Tahun 2020

Pasien COVID-19 yang dirawat di RSPI-SS Tahun 2020 menunjukkan sebagian besar kasus berasal dari wilayah kerja Jakarta Utara (288 pasien) namun tetap menerima kasus dari Jabodetabek, luar Jabodetabek dan luar negeri (WNA) (Gambar 3.)

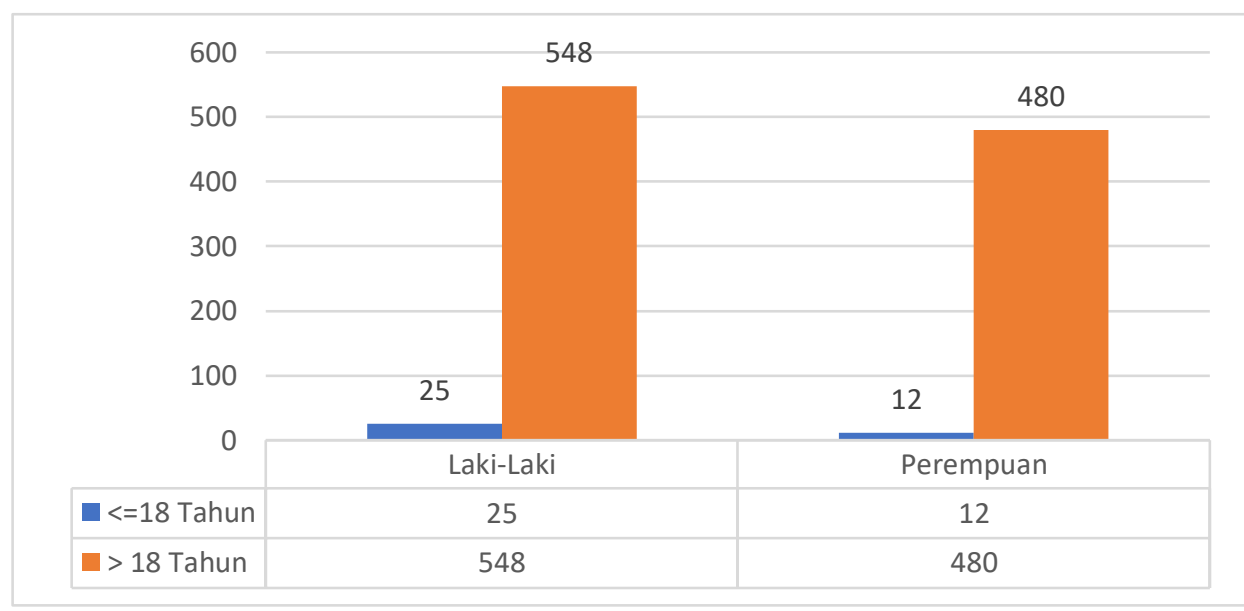

Grafik 2. Distribusi Pasien Rawat Inap COVID-19 di RSPI-SS Berdasarkan Umur dan Jenis Kelamin Tahun 2020

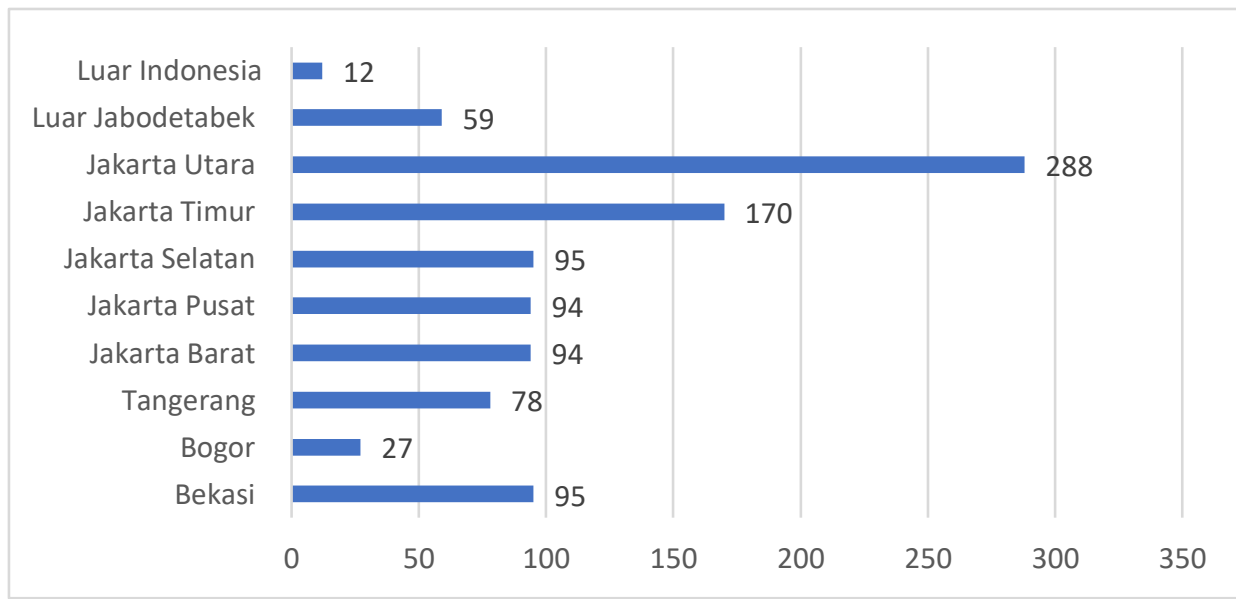

Grafik 3. Distribusi Pasien Rawat Inap COVID-19 di RSPI-SS Berdasarkan Domisili Tahun 2020 
Distibusi Pasien Rawat Inap COVID19 Berdasarkan Hasil PCR dan Luaran di RSPI Sulianti Saroso Tahun 2020

Hasil pemeriksaan PCR dikategorikan menjadi konfirmasi (positif) dan discorded (negatif). Hasil dikatakan discarded apabila pasien baru dengan 2 kali pemeriksaan PCR dengan hasil negatif. Hasil PCR terbanyak adalah hasil konfirmasi (880 pasien) dan cara keluar hidup (911 pasien). Pasien dengan pemeriksaan swab PCR dengan hasil terkonfirmasi dan cara keluar hidup adalah sebanyak 753 pasien sedangkan pasien dengan hasil laboratorium terkonfirmasi COVID19 dengan cara keluar meninggal sebanyak 127 pasien (Gambar 4).

\section{Distribusi Pasien Rawat Inap COVID-} 19 Berdasarkan Asal Rujukan di RSPI Sulianti Saroso Tahun 2020

Pasien COVID-19 yang dirawat di RSPI-SS Tahun 2020 menunjukkan sebagian besar kasus datang sendiri ke RSPI Sulianti Saroso, yaitu sebanyak $35 \%$ sedangkan rujukan dari rumah sakit swasta/klinik swasta berada di urutan ke dua yaitu sebanyak 34\%.

\section{Pembahasan}

Sebagai rumah sakit rujukan nasional kasus COVID-19, RSPI Sulianti Saroso mulai merawat pasien terduga kasus COVID-19 pada bulan Januari walaupun hanya ada 2 pasien dan pada bulan Februari bertambah menjadi 23 pasien dan jumlah pasien terus meningkat dan mencapai puncaknya pada bulan Desember yaitu sebanyak 170 pasien. Penemuan kasus terkonfirmasi PCR pertama kali diumumkan di Indonesia pada tanggal 2 Maret 2020 dan merupaka pasien rawat inap RSPI Sulianti Saroso. Setelah pengumuman kasus pertama tersebut, setiap hari dilaporkan pasien terkonfirmasi COVID-19. Sampai hari ini jumlah kasus masih terus meningkat dan menyebar di seluruh provinsi di Indonesia. Per 17 Agustus 2020 terdapat $1.068 \quad 945$ kasus positif dengan 6.207 kasus meninggal dan 483 kabupaten/kota terdampak. ${ }^{2}$

Berdasarkan kondisi tersebut maka pemerintah mengeluarkan kebijakan pada 31 Maret 2020 yaitu melakukan Pembatasan Sosual Berskala Besar (PSBB). Kebijakan ini bertujuan untuk menekan penyebaran COVID-19, karena kasus kontak langsung erat kaitannya dengan penyebaran COVID19. Pembatasan tesebut paling sedikit dilakukan melalui libur sekolah dan tempat kerja, pembatasan kegiatan agamaan dan atau pembatasan di tempat umum atau fasilitas umum dan pembatasan perjalanan internasional. ${ }^{2}$ 


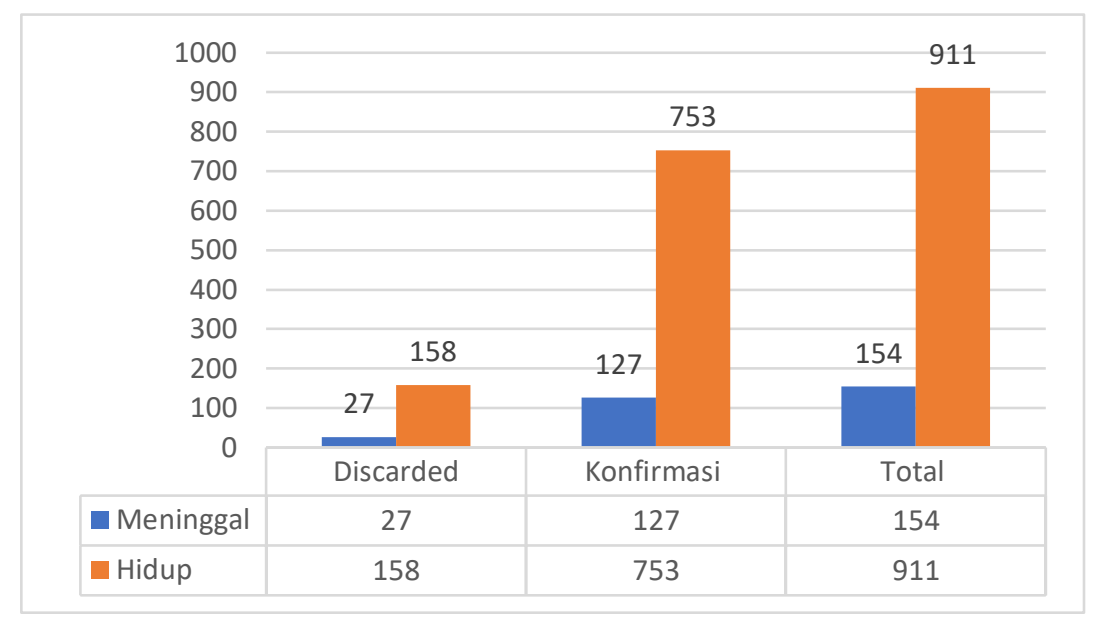

Grafik 4. Distribusi Pasien Rawat Inap COVID-19 di RSPI-SS Berdasarkan Hasil PCR dan Luaran Tahun 2020

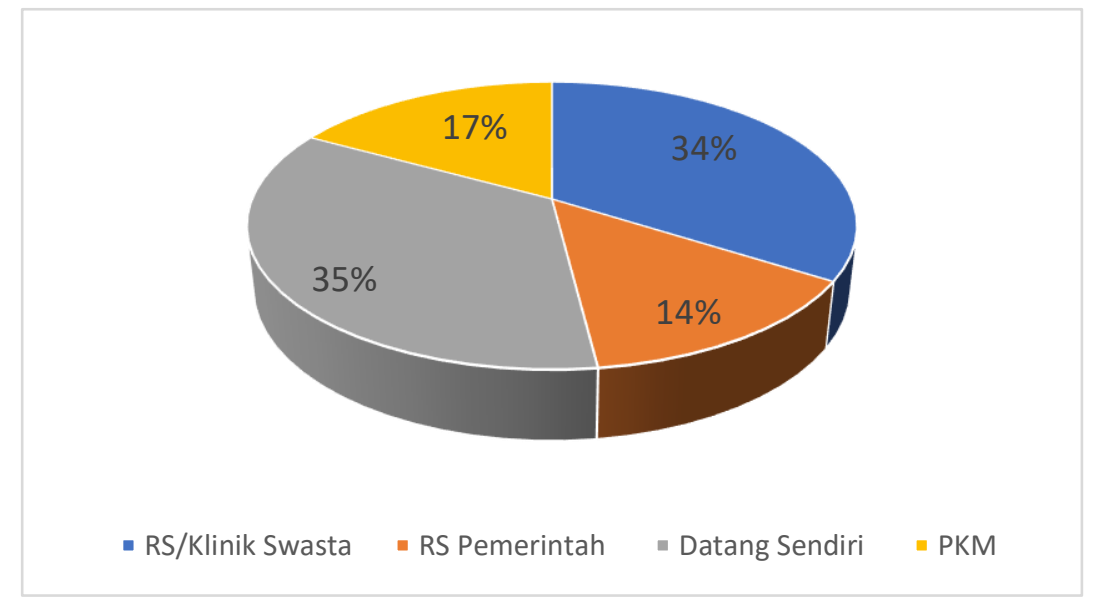

Grafik 5. Grafik Distribusi Pasien Rawat Inap COVID-19

Berdasarkan Asal Rujukan Tahun 2020

Penanggulangan pandemi COVID19 sampai saat ini masih berlangsung sehingga diperlukan suatu tindakan untuk penemuan kasus dan pencegahan penyebaran kasus. Adapun kegiatan tersebut dikenal dengan istilah surveilans. ${ }^{3}$ Tujuan untuk dilakukan surveilans yaitu dapat memantau tren penularan COVID-19, melakukan deteksi cepat pada wilayah tanpa transmisi virus dan monitoring kasus pada wilayah dengan transmisi virus termasuk pada populasi rentan, memberikan informasi epidemiologi untuk melakukan penilaian risiko, memberikan informasi epidemiologi sebagai acuan kesiapsiagaan dan respon penanggulangan serta memberikan eveluasi terhadap dampak pandemi pada sistem pelayanan kesehatan dan sosial. ${ }^{2}$ 
Peningkatan kasus COVID-19 masih terus terjadi di Indonesia dan DKI Jakarta merupakan kasus terbanyak sampaisaat ini maka diperlukan sosialisasi tentang surveilans untuk mengantisipasi penambahan kasus yang lebih banyak lagi setelah masa PSBB di cabut. ${ }^{5}$

Pasien rawat inap kasus COVID-19 paling banyak adalah laki-laki dengan usia lebih dari 18 tahun atau orang dewasa. Hasil ini sama dengan hasil penelitian Penyakit Virus Corona 2019 oleh Diah Handayani dkk, pada penelitian tersebut didapatkan hasil umur pasien yang terinfeksi COVID-19 mulai dari usia 30 hari hingga 89 tahun. Hasil ini sesuai dengan hasil laporan 138 kasus di Kota Wuhan, didapatkan rentang usia 37-78 tahun dengan rerata 56 tahun (42-68 tahun) tetapi pasien rawat ICU lebih tua (median 66 tahun (57-78 tahun) dibandingkan rawat non-ICU (37-62 tahun) dan $54,3 \%$ laki-laki. Laporan pasien terkonfirmasi COVID-19 di luar Kota Wuhan menunjukkan umur lebih muda dengan median 34 tahun (34-48 tahun) dan $77 \%$ laki laki. ${ }^{6}$

Pasien rawat inap kasus COVID-19 yang dirawat di RSPI Sulianti Saroso terbanyak berasal dari wilayah Jakarta Utara, yaitu sebanyak 288 pasien, dan terbanyak kedua berasal dari wilayah Jakarta Timur, yaitu sebanyak 170 pasien. Selain wilayah DKI Jakarta, pasien kasus COVID-19 yang di rawat di RSPI Sulianti Saroso juga berasal dari luar DKI Jakarta, yaitu Bekasi, Bogor, Depok, Tangerang bahkan ada juga yang berasal dari wilayah luar Jabodetabek dan juga wilayah luar negeri (WNA). Hal ini karena RSPI-SS sebagai rumah sakit rujukan pertama untuk kasus COVID-19 di Indonesia.

RSPI Sulianti Saroso sejak tanggal 1 April 2020 telah dapat melakukan sendiri pemeriksaan swab PCR COVID-19. Hasil pemeriksaan paling banyak adalah terkonfirmasi dengan luaran pasien sembuh yaitu sebanyak 753 pasien dan hasil terkonfirmasi COVID-19 dengan luaran pasien meninggal sebanyak 127 pasien. Selain hasil terkonfirmasi, pasien rawat inap juga didapatkan hasil discorded. Hasil discarded dengan luaran pasien hidup sebanya 158 pasien dan hasil discorded dengan luaran pasien meninggal sebanyak 27 pasien.

Berdasarkan rujukan, pasien rawat inap di RSPI Sulianti Saroso, paling banyak datang sendiri (35\%), rujukan rumah sakit swasta/klinik (34\%), rujukan PKM (17\%) dan rumah sakit pemerintah (14\%). Pasien terbanyak adalah berasal dari wilayah Jakarta Utara karena RSPI Sulianti Saroso sebagai rumah sakit rujukan terdekat 
dari masyarakat yang berdomisili di Jakarta Utara. Pasien lebih banyak datang sendiri ke RSPI Sulianti Saroso adalah adanya kebijakan pasien COVID-19 boleh langsungdatang ke rumah sakit tanpa sistem rujukan dan lamanya proses rujukan di puskesmas sehingga masyarakat memilih datang langsung ke rumah sakit.

\section{Kesimpulan}

Distribusi kasus COVID-19 berdasarkan waktu tertinggi pada bulan Desember, Distribusi berdasarkan orang terbanyak umur dewasa dan jenis kelamin laki-laki Distribusi kasus tempat terbanyak adalah wilayah Jakarta Utara. Distribusi kasus COVID19 berdasarkan hasil PCR terkonfirmasi dengan luaran pasien hidup/sembuh Hasil surveilans ini sangat dibutuhkan sebagai bahan evaluasi pelayanan dan evaluasi terhadap keberhasilan program pengendalian pandemik. Oleh karena itu sangat dibutuhkan dukungan data berupa kelengkapan laporan dan ketepatan waktu pelaporan terutama dari ruang rawat.

\section{Saran}

Perlunya kegiatan surveilans epiemiologi untuk dikembangkan menjadi surveilans yang lebih luas lagi seperti surveilans K3, surveilans resistensi obat, surveilans angka kuman udara dan lain-lainnya.

\section{Ucapan Terima Kasih}

Penulis mengucapkan terima kasih kepada Direktur Utama beserta seluruh jajaran Direksi RSPI-SS atas izin dan dukungan yang diberikan dan juga kepada semua pihak yang berkonstribusi dalam kajian ini.

\section{Daftar Pustaka}

1. WHO. Coronavirus Disease (COVID-19) Pandemic [Internet]. 2020. Available from: https://www.who.int/

2. Kementerian Kesehatan RI. Pedoman Pencegahan dan Pengendalian Corona Virus deases (Covid-19). 2020.

3. WHO. Coronavirus disease 2019 (COVID-19) situation report - 178.

4. Darmawan ES. Pengalaman Indonesia dalam Menangani Wabah COVID-19 Periode JanuariJuli 2020 Chapter: Peran Organisasi Profesi IAKMI. In: BNPB dan UI. 2020. p. 533-647.

5. Ayu IM, Handayani R, Sangadji NW. Sosialisasi Surveilans Dalam Menghadapi Covid-19 Gelombang Ke-2. J Pengabdi Masy AbdiMas. $2021 ; 7(2)$.

6. Handayani D, Hadi DR, Isbaniah F, Burhan E, Agustin H. Penyakit Virus Corona 2019. J Respirologi Indones. 2020;40(2):120-30. 